\title{
STUDI PERSEPSI MASYARAKAT KRISTEN: Perbedaan Pandang Gereja-Gereja Jabotabek Atas Roh Kudus
}

\author{
Robby Igusti Chandra \& Elia Tambunan
}

\begin{abstract}
This is a preliminary study to explore the relationship between the church denomination background with their members' perception of the Holy Spirit's role, the function of baptism in the Spirit, and the locus of the Holy Spirit's presence as how they percepted. Respondents were chosen based on cluster and availability in quantitative research approach. Before, it is hypothesized that subjects' denominational background as the independent variable correlates positively with their view of the Holy Spirit role, the function of Baptism in the Spirit, and their understanding about the presence of the Holy Spirit today. By using Pearson correlation test, it is found that no strong correlation between the subjects' denomination background with their view of the roles of the Holy Spirit, the function of Baptism in the Spirit, and the locus of the Holy Spirit's presence. Various possibilities were discussed to shed light of the phenomenon primarily in relation to the statements of many theologians that Western or some of Eastern churches tend to neglect holistic experience and theological concepts of the Spirit. The scientific contribution of this paper is to include the study of Christian perceptions as a field of study in practical theology, and also in Pentecostalism which has not been much in the Indonesian context.
\end{abstract}

Keywords: Perception, Roles, Baptism, Function, Holy Spirit, Church Denomination

Abstrak

Ini adalah studi pendahuluan untuk mengeksplorasi hubungan antara latar belakang denominasi gereja dengan persepsi anggotanya tentang peran Roh Kudus, fungsi baptisan dalam Roh, dan lokus kehadiran Roh Kudus sebagaimana persepsi mereka. Responden dipilih berdasarkan cluster dan ketersediaan dalam pendekatan penelitian kuantitatif. Sebelumnya, dihipotesiskan bahwa latar belakang kelompok keagamaan sebagai variabel independen berkorelasi positif dengan pandangan mereka tentang peran Roh Kudus, fungsi Baptisan dalam Roh, dan pemahaman mereka tentang kehadiran Roh Kudus dewasa ini. Dengan menggunakan uji korelasi Pearson, ditemukan bahwa tidak ada korelasi yang kuat antara latar belakang denominasi subyek dengan pandangan mereka tentang peran Roh Kudus, fungsi Baptisan dalam Roh, dan tempat kehadiran Roh Kudus. Berbagai kemungkinan dibahas untuk menjelaskan fenomena ini terutama sehubungan dengan pernyataan banyak teolog bahwa gereja-gereja Barat atau Timur cenderung mengabaikan pengalaman holistik dan konsep-konsep teologis Roh. Sumbangan ilmiah dari tulisan ini ialah memasukkan studi persepsi masyakat Kristen sebagai satu bidang kajian dalam teologi praktika, dan juga dalam Pentakostalisme yang belom banyak dalam konteks Indonesia.

Kata kunci: Persepsi, Peran, Pembaptisan, Fungsi, Roh Kudus, Denominasi Gereja 


\section{Pendahuluan}

Suatu penelitian awal mengenai hubungan latar belakang Gereja dengan pandangan warga jemaat mengenai peran Roh Kudus, fungsi Baptisan Roh, dan kehadiran Roh Kudus secara nyata di masa kini ialah sesuatu yang penting. Jurgen Moltmann, salah satu teolog protestan terkemuka di dunia pernah mengatakan apa yang kita alami setiap hari sebagai "roh kehidupan" adalah Roh Tuhan. Pernyataan itu memberi Moltmann ruang untuk memperlakukan aspek-aspek kehidupan yang berbeda dalam Roh semangat dan vitalitas yang konkret dan eksistensial. Memang Moltmann mengembangkan teologi Roh Kudus yang menghubungkan pengalaman komunitas Kristen tentang Roh dengan pengudusan dan pembebasan hidup yang memiliki bukan hanya mencakup lingkup ekologis tetapi juga politis dari kepercayaan Kristen terhadap Trinitas. ${ }^{152}$ Masalah lanjutan sebagai wujud perkembangan dari penjelasan itu ialah bagaimana realitanya di dalam kehidupan masyarakat Kristen di Indonesia sekarang?

Oleh karena itu, tulisan ini merupakan riset empiris terhadap sejumlah gerejagereja yang berbeda pandang mengenai Roh Kudus.

Membahas mengenai topik Roh sebagai ajaran dalam Kristen tidak akan utuh tanpa membahas mengenai peran dan fungsi Roh Kudus di gereja sekarang. Sayangnya, pemahaman masyarakat Kristen yaitu, warga gereja yang berbeda denominasi mengenai Roh Kudus seperti diajarkan di pendidikan tinggi keagamaan Kristen, selalu bersifat idiografis dan biasanya penelitian tentang hal itu menggunakan pendekatan kualitatif. Sifat itu didasarkan pada pandangan bahwa seseorang hanya dapat memahami dunia sosialnya (termasuk pula dibentuk oleh pengetahuan, pemahaman dan pengalaman teologis) yang diperoleh dari tangan pertama di sekitar kehidupan. ${ }^{153}$ Di sini, perlu diketahui, pemahaman masyarakat Kristen atas ajaran-ajaran gereja yang bernuansa praktis tidak terjadi secara alamiah ataupun bersifat kosmik karena karya Allah tetapi juga merupakan konstruksi secara sosial yang berproses di mana mereka berada. ${ }^{154}$ Ringkasnya, pandangan warga gereja tentang seluruh ajaran selalu bersifat bentukan bukan alamiah. Artinya ada alasan kuat untuk mempertimbangkan perlunya melakukan studi persepsi masyakat Kristen yang terkait langsung dengan realitas teologis praktika, dan juga hal-hal yang terkait dengan fenomena Pentakostalisme, yang belum banyak dikerjakan oleh para teolog, akademisi dalam hal kerja-kerja empiris keilmiahan maupun pelayanan kegerejaan dalam konteks Indonesia. 
Peneliti membangun pra-asumsi ilmiah ataupun yang biasa dipahami sebagai pemahaman hipotetik, bahwa latar belakang aliran atau denominasi gereja warga jemaat korelatif dengan pandangannya mengenai lokus kehadiran Roh Kudus. Meskipun hal itu memang telihat umum, tetapi yang justru menarik untuk ditindaklanjuti dalam riset empiris. Itulah alasannya penelitian ini menggunakan pendekatan kuantitatif (bukan kualitatif) untuk mengujinya secara lebih faktual. Seperti diketahui dalam kaidah-kaidah kuantitatif yang dipakai juga dalam ilmu teologi pada umumnya di pendidikan tinggi Barat seperti yang pernah dijelaskan John Swinton dan Harriet Mowat, salah satu dari sekian banyak karakteristiknya ialah untuk menyusun pemahaman nomotetik yang berupaya membuat hukum-hukum dari generalisasinya setelah mengetahui perilaku dan sikap berdasarkan ukuran kuatifikasi yang dirancang. 155

Pemahaman nomotetik atas Roh Kudus di dalam gereja-gereja yang berbeda penting diketahui bukan semata-mata untuk melakukan generalisasi pengetahuan (seperti yang dipahami oleh sarjana riset kuantitatif selama ini156) tentang Roh Tuhan tersebut secara terpaksa. Akan tetapi, dalam tulisan ini peneliti justru hendak menunjukkan penjelasan dan pemahaman tentang bagaimana sebenarnya masyarakat Kristen di gereja mengalami proses pembentukan persepsi mereka atas pengajaran itu. Dengan demikian, ukuran kuantitatif tentang bagaimana persepsi publik masyarakat Kristen yang tidak selalu sama bukan hanya karena berbeda denominasi secara tunggal seperti yang sudah umum diketahui selama ini secara salah tetapi juga diakibatkan oleh hal-hal lain yang sifatnya kompleks sehingga riset empiris penting dilakukan.

Untuk mampu meneliti pembentukan persepsi itu, maka dalam tulisan ini, peneliti memberikan fokus perhatian secara khusus kepada perbedaan mengenai ayat-ayat Perjanjian Baru yang populer mengenai Roh Kudus. Seperti apa intensitas asupan pelajaran itu di dalam gereja lewat khotbah untuk membina umat tentang Roh Kudus. Bagaimana pandangan mereka mengenai peran Roh Kudus dan fungsi baptisan Roh dalam hidup beriman. Tentu saja dengan hal-hal ini akan dapat diketahui perhatian serta pemahaman mereka yang bervariasi mengenai "kehadiran" Roh Kudus di masa kini. Pemahaman akan Roh Kudus akan diukur dengan data empiris setelah melakukan kajian

155 John Swinton, Harriet Mowat, Practical Theology and Qualitative Research Second Edition (London: SCM Press, 2016), 42-43.

${ }^{156}$ Zoe Bennett, Elaine Graham, Stephen Pattison, Heather Walton, Invitation to Research in Practical Theology (London and New Yok: Routledge, 2018), 1. 
mengenai bagaimana warga jemaat memahami peran Roh Kudus dan Baptisan dalam Roh, khususnya di Jabotabek, Indonesia.

\section{Ragam Pandangan Gereja Mengenai Roh Kudus}

Perbedaan ajaran gereja tentang Roh Kudus bukan lantas membuat Roh Tuhan di dalam gereja dan masyarakat Kristen itu beda. Ia berbeda hanya karena teologi Roh Kudus yang tidak sama diajarkan oleh gereja. Ia beda hanya karena persepsi, pengalaman dan ekspresi ataupun selebrasi warga jemaat saja yang tidak seragam.

Salah seorang teolog yang berdampak luas, Agustinus, sang Bapa Gereja dari Afrika yang hidup di tahun 354 sampai 430 Masehi lama merenungkan hal itu. Menurut legenda yang populer, Agustinus berjalan kaki menelusuri sebuah pantai di Hippo di Afrika utara sambil merenungkan mengenai misteri Tritunggal. Selagi melangkah, ia melihat seorang anak laki-laki berlari bolak-balik dari tepi laut sambil menenteng ember berisi air dan mengisinya ke sebuah lubang kecil di pasir pantai. Agustinus yang merasa heran bertanya: "Apa yang kau lakukan?" Sang anak menjawab: "Saya sedang mencoba menampung seluruh air laut itu di lubang ini." Mendengar jawaban itu, Agustinus bertanya kembali, "Mana mungkin? Laut itu begitu luas dan lubang itu sangat kecil." Sang anak berespon: "Kalau begitu bagaimana bapa mengharapkan untuk memasukkan luasnya misteri Tritunggal ke dalam benak bapa yang kecil?" Lalu, anak itu menghilang. ${ }^{157}$ Narasi yang bergema di gereja dunia awal tersebut memberikan pembelajaran penting. Kesadaran Agustinus mengenai keterbatasan manusia dalam memahami Keallahan yang Tritunggal namun manunggal perlu menjadi dasar pembahasan mengenai Roh Kudus. Dari sana, tampak jelas bahwa ia hendak menekankan bagaimana sulit untuk membahas dan memahami mengenai Roh Kudus. Padahal, salah satu ungkapan dari Fulton J. Sheen yang populer di kalangan gereja modern abad 19 khususnya masyarakat gereja Amerika Serikat ialah keinginan dasar untuk pencarian atau pun bahkan mempertanyakan tentang ketuhanan menjadi sesuatu yang penuh maknawi bagi kehidupan manusia. ${ }^{158}$

${ }^{157}$ Lihat, tulisan Marian Horvat, Augustine and the Seashell, https://www.traditioninaction.org/religious/h065rp.Shell.html. diunduh 21 September, 2019.

${ }^{158}$ Fulton J. Sheen adalah seorang uskup Amerika dari Gereja Katolik yang dikenal karena khotbah dan terutama karyanya di televisi dan radio. Ditahbiskan sebagai Imam di Keuskupan Peoria pada tahun 1919, Sheen dengan cepat menjadi seorang teolog terkenal, mendapatkan penghargaan untuk Filsafat Internasional pada tahun 1923. Lihat, Fulton J. Sheen, The Divine Romance (Chicago: Brietta Books, 2014), 5. 
Joseph Ratzinger yang lahir di tahun 1927 dan kemudian menjadi Paus Benedict XVI sampai tahun 2013 menggemakan pandangan tersebut dengan tulisannya bahwa, Roh Kudus menarik diri dari kita untuk masuk ke misteri, melebihi Kristus dengan misteri-Nya. ${ }^{159}$ Lalu, yang menjadi pertanyaan penting ialah bagaimana kelanjutan kesadaran mengenai misteri dan Roh Kudus yang sudah lama dikenali sejak zaman Bapabapa Gereja dikenali oleh umat Kristiani dan apa kaitannya dengan topik Baptisan Roh atau Baptisan dalam Roh?

Menurut teolog yang menjadi pengajar di Fuller Seminary yang berasal dari Finlandia, Veli-Matti Karkkainen, gereja-gereja Barat terkesan menekankan pengembangan teologi dan spiritualitas yang berpusat pada Kristus. Pembahasan mengenai siapa dan peran Kristus yang terutama terkait dengan penebusan, pendamaian, atau keselamatan menarik energi para teolog, terutama di zaman modern. Sebagai bandingannya, Gereja-gereja Orthodox sangat ditekankan eksplorasi tentang dan pengalaman dengan Roh Kudus dalam kerangka Allah Tritunggal. ${ }^{160}$ Dengan demikian Roh Kudus sering jadi topik yang tidak banyak dibahas dan dicarikan praksisnya di kalangan Gereja-gereja yang kita kenal di Indonesia, karena akarnya di dalam spiritualitas dan teologi Gereja-gereja Barat.

Lebih lanjut, Karkkainen menunjukkan keberagaman, teologi dan pengalaman dengan Roh Kudus sangat diwarnai kepelbagaian aliran Gereja, konteks sosial budaya setempat dimana mereka berada, serta sejarah gereja masing-masing. Untuk abad XXI, secara sederhana hal itu dapat dipaparkan sebagai berikut. Di abad XX, Gerakan-gerakan Pentakosta muncul dengan memusatkan perhatian pada pengalaman mereka dengan Roh Kudus. Bila dipandang secara sepintas, tekanan pada pengalaman bernuansa supernatural dan emosional sangat kuat di dalam kalangan ini. Sementara pada Gereja Roma Katolik fokus pada kaitan Roh Kudus yang penuh misteri dengan sakramen dan ibadah sangat kuat dan di Gereja-gereja Protestan dalam keberagamannya, khususnya kalangan Injil lebih menekankan kaitan Roh Kudusnya dengan Firman Tuhan sedangkan kalangan yang dikenal dengan Gereja arus utama lebih mengaitkan Roh Kudus dengan

${ }^{159}$ Joseph Ratzinger, "The Holy Spirit as Communio: Concerning the Relationship of Pneumatology and Spirituality in Augustine,” Communio: International Review, Vol. 25, No. 2 (1998): 324-339.

${ }^{160}$ Veli-Matti Karkkainen, Pneumatology: The Holy Spirit in Ecumenical, International, and Contextual Perspective Second Edition (Grand Rapids, Michigan: Baker Academic, 2018). 
ibadah dan doa. ${ }^{161}$ Namun, setelah Sidang Raya Gereja Dunia/WCC di Canberra, pada tahun 1991, terjadilah perubahan dalam tingkat kesadaran mengenai perlunya menelusuri dan memiliki pengalaman dengan Roh Kudus secara lebih utuh. Hal ini terjadi karena kehadiran dan partisipasi aktif gereja-gereja Pentakostal dan Karismatik serta Gereja Roma Katolik dan Orthodox di dalam dialog-dialog di persidangan Gereja tersebut.

Perbedaan tekanan teologi dan pengalaman mengnai Roh Kudus dalam gereja, seperti telah disinggung di atas menarik untuk didalami kembali. Frank D. Macchia dari kalangan Assembly of God yang berkecimpung juga di kalangan ekumenis menekankan bahwa, perbedaan-perbedaan pandangan teologis dan pengalaman dengan Roh Kudus khususnya tentang Baptisan dalam Roh dapat dibedakan ke dalam tiga kelompok. Bagi Gereja Orthodox dan Roma Katolik, baptisan dalam Roh dipandang sebagai tindakan sacramental (inisiasi). Bagi Gereja-gereja aliran Calvinis, baptisan dalam Roh dikaitkan terutama dengan pertobatan, kelahiran kembali atau kelahiran baru. 162

Sedangkan oleh Eddy Lanz, seorang dosen sistematik teologi dari Zarephath Theological Seminary, Pakistan, dalam bukunya Seven Truths about the Holy Spirit, memaparkan bahwa peran Roh Kudus sangat beragam. Mulai dari paparan di Perjanjian Lama, ditekankan Roh Kudus yang terlibat dalam Penciptaan semesta, memelihara ciptaan Allah, memberikan penghakiman, dan keselamatan. Ia juga memampukan orang, memberikan hidup baru, dan mencurahkan kuasa. Di dalam Perjanjian Baru, peran Roh Kudus terkait erat dengan Tuhan Yesus. Ia terkait dengan Firman Allah, Ia juga terkait dengan kelahiran baru, mempersatukan orang-orang percaya, memberikan kuasa bagi yang percaya pada-Nya, menjadi saksi yang efektif tentang Kristus, memperkuat hidup iman orang percaya, memimpin, membersihkan, mengajar, membimbing, mengajarkan mengenai masa depan, dan memberikan karunia-karunia. ${ }^{163}$

Kemudian, Joshua Ong, tokoh sistematik teologi dari Sekolah Tinggi Teologi IMAN dari Gereja Santapan Rohani Indonesia Jakarta memberikan paparan serupa. Pakar ini mengklasifikan peran Roh Kudus sebagai terkait dengan dunia/semesta dan kemanusiaan, dengan Alkitab, dengan Tuhan Yesus, dengan keselamatan, dan juga

\footnotetext{
${ }^{161}$ Ibid, Veli-Matti Karkkainen.
}

${ }^{162}$ Frank D. Macchia, Jesus the Spirit Baptizer: Christology in Light of Pentecost (Grand Rapids, Michigan: W.B. Eerdmans Publishing 2018); Frank D. Macchia, Justified in the Spirit: Creation, Redemption, and the Triune God (Grand Rapids, Michigan: W.B. Eerdmans Publishing 2010), 15-102.

${ }^{163}$ Eddy Lanz, Seven Truths about the Holy Spirit (Rawalpindi, Pakistan: GNU Free Documentation License 2013), 232-304. 
dengan hidup orang percaya. Sedangkan pada umumnya, di kalangan Protestan sebelum abad 18, aliran-aliran di dalam kalangan ini sangat menekankan keyakinan bahwa, baptisan dengan atau dalam Roh Kudus terkait dengan pertobatan atau hidup baru dalam keselamatan. Di pertengahan abad 18, di kalangan Methodis, ditekankan juga ajaran mengenai proses pengkudusan atau penyucian yang harus melanjutkan namun sangat terkait dengan keselamatan yang diterima seseorang. Pandangan ini mewarnai aliran Pentakosta yang awal. Bagi mereka Baptisan dengan Roh merupakan tahap kedua setelah keselamatan atau penebusan diterima oleh seseorang. 164

Jika melihat perspektif Asia tentang Roh Kudus, seorang teolog keturunan Korea yang mengajar di Bethany College, California, Koo Dong Yun menulis buku Baptism in the Holy Spirit: An Ecumenical Theology of Spirit Baptism. Di dalam buku itu ia menyatakan bahwa, selain ada sembilan pandangan teologi yang berbeda-beda mengenai baptisan dalam Roh, misalnya dari kalangan Katolik Roma, Lutheran, Dispensasional, Pentakostal, and Calvinis. ${ }^{165}$ Namun, ia juga menekankan adanya kesamaan-kesamaan universal di antara perbedaan yang ada.

Jika menilik ulang ke dekade awal Gerakan Pentakosta, menurut Frank D. Macchia, tekanan pada baptisan Roh sangat kuat disertai dengan manifestasi karunia lidah, dan berbagai karunia yang supernatural seperti digambarkan oleh Kitab Kisah Rasul dan 1 Korintus 11 sampai 14. Menurut teolog ini, ajaran pada saat itu sangat menekankan panggilan Tuhan agar manusia memiliki Roh Tuhan yang berdiam di dalam dirinya sebagai pengaruh dari ajaran Wesley mengenai proses penyucian atau pengkudusan seumur hidup dan Gerakan Kesucian (Holiness Movement). ${ }^{166}$ Sedangkan menurut Karkainnen dalam bukunya, The Spirit in the World: Emerging Pentacostal Theologies in Global Context, sulit untuk menentukan apakah di tengah kepelbagaian ajaran di kalangan Pentakostal, terdapat sebuah pusat yaitu, Baptisan dalam Roh ataukah sebenarnya hal itu tidak demikian. ${ }^{167}$

${ }^{164}$ Kirsteen Kim, The Holy Spirit in the World: A Global Conversation (New York: Orbis Books, 2007), 3-8; Frederick Dale Bruner, A Theology of the Holy Spirit: The Pentecostal Experience and the New Testament Witness (Eugene, Oregon: Wipf and Stock Publishers, 1997).

${ }^{165}$ Koo Dong Yun, Baptism in the Holy Spirit: An Ecumenical Theology of Spirit Baptism (Lanham, Maryland: Universitas Press of America, 2003), 188.

${ }^{166}$ Frank D. Macchia, "Baptized in the Spirit: Toward a Global Theology of Spirit Baptism," dalam Veli Matti Karkainnen (ed), The Spirit in the World: Emerging Pentacostal Theologies in Global Context (Grand Rapids, Michigan: W.B. Eerdmans Publishing 2009).

${ }^{167}$ Ibid., Frank D. Macchia. 
Simon Chan, seorang pengajar teologi sistematik dari Trinity Theological Seminary, Singapore menyatakan sebenarnya kalangan Pentakosta tidak sepakat mengenai apa saja yang merupakan keyakinan khas mereka, namun, apa yang sering muncul di dalam diskusi dan tulisan-tulisan dari kalangan ini adalah suatu pengalaman spiritual yang intens, langsung, dan menakjubkan serta terpusat pada pribadi Kristus. Pengalaman itu disebut sebagai baptisan di dalam Roh."168 Hal ini memang benar, karena di awalnya Gerakan Pentakosta menekankan karunia bahasa lidah, penyembuhan, dan akhir zaman atau kedatangan Kristus kedua kali dengan sangat mendalam dan bahkan, emosional.

Sekali lagi, bagaimana sebenarnya pandangan-pandangan di dalam kalangan Pentakosta dan Karismatik yang memiliki lebih dari 290 juta penganut? Ajaran atau doktrin kalangan Pentakostal dan Karismatis tidak mudah dirumuskan dalam suatu kesimpulan karena, kepelbagaian di antara mereka sangat luas sejak mereka hadir di awal abad 20. Namun, terutama, dinamika yang hidup di kalangan ini sangat besar dan dikaitkan dengan pengalaman intens dengan kehadiran dan kuasa Roh Kudus dalam kepelbagaian manifestasinya, bukan terutama pada upaya merumuskan dengan sistematis dan secara konseptual sesuai kaidah Barat mengenai kayanya pengalaman tersebut. Bagi mereka, momen-momen hidup ini adalah saat eskatologis artinya, saat dimana Kristus dapat datang kembali, untuk kedua kalinya.

Jadi, kesamaan mereka terletak pada tekanan akan pentingnya pengalaman baptisan dalam Roh. Bagi kalangan ini, baptisan dalam Roh dihayati dapat sebagai pencurahan kuasa untuk melakukan kesaksian dalam menjalani hidup namun ada pula yang memandangnya secara berbeda. ${ }^{169}$ Ada yang menekankan perlunya orang mengalami kelahiran kembali, lalu berlanjut menjalani keseluruhan proses penyucian, dan akhirnya menerima baptisan Roh. Ada pula yang menekankan bahwa, kelahiran kembali dan penyucian (dua hal yang tidak terpisah) merupakan persiapan menuju hidup dalam kepenuhan Roh. Bahkan, ada yang menangkap pengalaman dengan Roh Kudus berbeda yaitu, bahwa baptisan dalam roh merupakan pengalaman kelahiran baru lalu

${ }^{168}$ Simon Chan, Pentecostal Theology and the Christian Spiritual Tradition Reprinted (Sheffield, UK: Sheffield Academic, 2003).

${ }^{169}$ Frank D. Macchia, Baptized in the Spirit: A Global Pentecostal Theology (Grand Rapids, Michigan: Zondervan, 2006). 
penyucian adalah proses perjalanan sepanjang hidup orang yang percaya. ${ }^{170}$ Asal dari perbedaan tersebut dijelaskan oleh Donald Dayton, seorang teolog dari Northern Baptist Theological Seminary, Lombard, Illinois. Bagi aliran Pentakosta yang awal, akar dari pengalaman dengan Roh Kudus terkait dengan penghayatan atas peran Kristus sebagai Juruselamat, Pembaptis dalam Roh, Penyembuh/pemberi pemulihan, dan Raja yang Datang sangat ditekankan. ${ }^{171}$

Perlu diperhatikan, bahwa bagi kalangan Pentakosta dan karismatik terutama di abad yang lalu, ciri kehadiran baptisan Roh Kudus dikaitkan dengan pengalaman menerima tanda-tanda atau karunia-karunia Roh seperti, berbicara dalam bahasa lidah, penglihatan, dan sebagainya. Dasar pengalaman itu adalah apa yang dicatat pada hari Pentakosta di dalam Kisah Para rasul. Beberapa kalangan Pentakosta tradisional bahkan menekankan tanpa tanda-tanda supernatural tersebut, maka pengalaman keselamatan seseorang dapat diragukan. Hampir seluruhnya menggambarkan bahwa, peran Roh Kudus bagi Gereja dan orang-orang Kristen secara di dalam periode akhir sangat menonjol.

Pada tahun 1991, peran Roh Kudus dan baptisan di dalamnya mulai dipandang tidak hanya terkait dengan pembaharuan hidup individual dan hidup Gereja, namun juga seluruh ciptaan. Hal ini menggemakan ajaran dari bapa-bapa Gereja Capadocia di abad ke $4 .{ }^{172}$ Selain itu, muncul suasana yang menekankan bahwa, melalui baptisan, orangorang Kristen dipersatukan dengan Kristus, dengan satu sama lain, dan dengan Gereja di segala masa dan tempat. Commission on Faith and Order (komisi Iman dan Tata Gereja dari the World Council of Churches menyatakan dalam dokumen, "Baptisan, Ekaristi, dan Pelayanan" bahwa, baptisan itu menjadi dasar penyatuan keberagaman berbagai kalangan Kristiani. Lebih daripada itu, tulisan-tulisan Jurgen Moltmann yang mendorong orang untuk menyadari bahwa, Roh Kudus tidak hanya berperan pada lingkup hidup pribadi dan Gereja saja, namun dalam keseluruhan semesta ciptaan Tuhan, khususnya umat manusia. Bahkan dari kalangan Pentakosta dan Kharismatik muncul dinamika yang kuat, dimana peran Roh Kudus serta Baptisan dalam Roh menjadi konsep yang diperluas.

\footnotetext{
${ }^{170}$ Bandingkan dengan paparan yang dilakukan oleh Max Turner, The Holy Spirit and Spiritual Gifts, Then and Now (Cumbria, UK; 1996), Chapter 2. 1987).

${ }^{171}$ Donald Dayton, Theological Roots of Pentecostalism (Grand Rapids, Michigan: Baker Academic,

${ }^{172}$ Sigurd Bergmann, Creation Set Free: The Spirit as Liberator of Nature (Grandrapids, Michigan and Cambridge, UK: Wm. B. Eerdmans Publishing Company, 2005), 154-155.
} 
Dari penelusuran di atas, jelaslah ada perbedaan yang signifikan antara fokus perhatian dan enerji yang dituangkan oleh berbagai aliran di dalam Kekristenan terkait dengan Roh Kudus. Ada yang lebih menekankan pengalaman dengan Roh Kudus dan ada yang juga lebih menekankan penyusunan paham teologis dalam hal ini pneumatologi yang terstruktur. Selanjutnya, baptisan dalam Roh juga lebih dijadikan pengalaman yang menjadi perhatian kalangan Pentakostal dan Karismatis. Terlepas dari pemaparan di atas, untuk lingkup pendidikan tinggi dan gereja di Indonesia masih belum banyak tulisan yang meneliti secara empiris bagaimana pemahaman warga jemaat mengenai peran Roh Kudus, fungsi Baptisan dalam Roh, dan bagaimana Gereja berperan membina mereka mengenai hal itu terutama dalam pengajaran-pengajaran selama ini.

\section{Metode Penelitian}

Berdasarkan latar belakang teoretis yang ada, sejumlah pertanyaan telah dirumuskan untuk mengukur beberapa variabel maupun dengan sejumlah indikator. Pertama, apakah latar belakang Gereja orang-orang yang diteliti berkorelasi positif dengan perhatian orang-orang yang diteliti dengan teks-teks Alkitab yang populer mengenai Roh Kudus? Kedua, apakah latar belakang Gereja orang-orang yang diteliti berkorelasi positif dengan frekuensi asupan yang diterima warga jemaat masing-masing melalui kotbah mingguan? Ketiga, apakah latar belakang Gereja orang-orang yang diteliti berkorelasi dengan pemahamannya tentang peran Roh Kudus di dalam hidup iman? Keempat, apakah latar belakang Gereja orang-orang yang diteliti berkorelasi dengan pemahamannya tentang fungsi Baptisan Roh Kudus? Kelima, apakah latar belakang Gereja orang-orang yang diteliti berkorelasi dengan pemahamannya tentang lokasi kehadiran Roh Kudus di masa kini?

Untuk mengumpulkan data, peneliti melakukannya dengan menyebarkan kuesioner kepada 123 responden. Perlu ditegaskan, responden yang dimaksudkan adalah masyarakat Kristen yang adalah jemaat gereja di kawasan Jabodetabek yang berjemaat di gereja yang berbeda aliran teologis dan denominasi. Artinya, dalam penelitian ini, sampel tersebut juga kadang disebut sebagai subjek ataupun responden. Sejumlah masyarakat gereja, yakni 123, tersebut dijadikan sebagai contoh yang mewakili yang biasa dikenal sebagai sampling. Lewat teknik sampling yang ada, warga jemaat Kristen di Jabodetabek ditentukan secara acak untuk mengukur persepsi publik mereka 
yang biasa dipakai sebagai instrumen penilaian akan adanya pemahaman yang beragam tentang Roh Kudus.

Agar diperoleh kesahihan pemahaman masyarakat Kristen yang disurvei dan demi terhindarnya bias responden terhadap pengetahuan mereka mengenai ajaran Roh Kudus di gereja masing-masing, maka dipilih respon yang ada tersebut dari jemaat yang sudah dewasa secara usia, yakni dalam rentang usia 36 hingga 60 tahun. Sementara teknik penyamplingan dilakukan berdasarkan metode clustering. Peneliti membuat cluster gereja berdasarkan kesepahaman-kesepahaman umum yang sudah lama ada di kalangan gereja-gereja di Indonesia yang berada di bawah atap PGI yang tentu saja sesuai availabilitas mereka. Dalam penelitian ini, mereka diclusterkan ke dalam tiga. Mereka adalah kalangan arus utama yang terdiri dari gereja GKI, GKSBS, GKK. Cluster selanjutnya ialah Injili. Sedangkan cluster lainnya ialah Pentakosta/Karismatik yang kami satukan saja demikian untuk mempermudah proses clusteringnya semata. Waktu pelaksanaan penelitian terjadi pada bulan September 2019.

Dari hasil yang diperoleh, peneliti melakukan analisis korelasi. Seperti pada umumnya diterima dalam metode penelitian kuantitatif, uji korelasi adalah metode statistik yang digunakan untuk mengevaluasi kekuatan hubungan antara dua variabel kuantitatif yang telah ditentukan oleh peneliti dengan kaidah-kaidah yang tepat, teruji dan dapat digunakan. ${ }^{173}$ Dalam penelitian jenis ini, seperti biasa dipakai oleh para praktisi riset kuantitatif, hasil analisis penelitian disebut memiliki korelasi yang tinggi apabila dua atau beberapa variabel memiliki relasi yang kuat satu sama lain. Sebaliknya, dianggap lemah satu korelasi apabila hasil uji yang dilakukan menunjukkan variabelvariabel yang diukur tidak berhubungan satu sama lain. ${ }^{174}$

Untuk kerja akademik yang lebih tepat, maksudnya sesuai dengan tujuan penelitian, peneliti memilih untuk menggunakan Pearson Correlation Test. Dalam bidang teologi praktika ataupun praksis teologi di masyarakat, seperti pernah dipakai oleh Mark J. Cartledge, korelasi Pearson berguna untuk menguji kekuatan atau tingginya keterhubungan atau korelasi antara beberapa variabel antara variabel dependen yaitu

173 Elia Tambunan, Desain Riset: Bagaimana Menulis Proposal Pendidikan, Teologi dan Agama (Yogyakarta: illumination Publishing, 2013), 116.

${ }^{174}$ Ahono Telesia Atetwe, Jairo Peter Aloka, Calleb Owino Gudo, "Influence of Efficacy Expectation on Mathematics Achievement among Students in Secondary Schools in Kenya," International Journal of Education and Research, Vol. 6 No. 8 (August 2018):141-151. 
latar belakang denominasi gereja dengan variabel-variabel lainnya yang dikaitkan. ${ }^{175} \mathrm{Uji}$ ini tepat dipakai dalam bidang teologi secara empirik. Karena sebagai instrumen uji, ia bisa dipakai untuk mengukur pemahaman warga gereja dengan ajaran internal maupun eksternal masing-masing. ${ }^{176}$ Dalam hal ini, uji itu akan digunakan untuk mengukur korelasi antara latar belakang Gereja responden dengan tingkat perhatian dan frekuensi asupan mengenai Roh Kudus melalui kotbah mingguan setiap tahun; antara latar belakang Gereja subjek dengan pemahaman subjek mengenai konsep Baptisan dalam Roh khususnya, hubungan baptisan dalam Roh dengan baptisan air dan sebagainya; antara latar belakang Gereja subjek dengan pemahaman subjek mengenai fungsi baptisan dalam Roh; antara latar belakang Gereja subjek dengan pemahaman subjek mengenai peran Roh Kudus; antara latar belakang Gereja subjek dengan kedekatan subjek dengan ayat-ayat sinoptik dan kisah Rasul yang terkait dengan baptisan dan peran Roh Kudus; dan antara latar belakang Gereja subjek dengan lokasi kehadairan Roh Kudus.

Persepsi Masyarakat Kristen Jabotabek Atas Roh Kudus

Tidak terbantahkan, bahwa secara persepsi latar belakang gereja memiliki korelasi secara kuat dengan pandangan tentang peran Roh Kudus. Latar tersebut juga korelatif terhadap ketidakseragaman persepsi masyarakat Kristen dari berbagai kalangan mengenai peran Roh Kudus dalam hidup orang beriman di sekitar Jabodetabek. Akan tetapi, dalam uji empiris lewat responden yang ada, tidak ada korelasi yang kuat antara latar belakang denominasi subyek yang diteliti dengan pandangan mereka tentang peran Roh Kudus. Seperti telah dijelaskan sebelumnya, untuk mengukur persepsi masyarakat Kristen atas Roh Kudus dilakukan dengan uji test model Pearson. Dari uji tersebut diperoleh hasil analisis data sebagai berikut yang menarik untuk dipahami.

Pertama, korelasi antara latar belakang gereja dan pandangan tentang peran Roh Kudus. Ini mengukur persepsi masyarakat Kristen dari berbagai kalangan mengenai peran Roh Kudus. Di dalam Pearson Correlation Test, hasil penelitian dapat menggambarkan tingkat korelasi yang tinggi antara dua variabel, dalam hal ini latar belakang denominasi yaitu, kalangan Gereja arus utama, Gereja-gereja Injili, dan Gereja

175 Mark J. Cartledge, Practical Theology: Charismatic and Empirical Perspectives (Eugene, Oregon: Wipf \& Stock, 2012), 69-110.

176 Elia Tambunan, Metodologi Riset: Dari Skill Mendesain Proposal Teologi \& PAK hingga Mempublikasikan (Yogyakarta: illumination Publishing, 2012), 156. 
Pentakostal/Karismatis dengan variabel peran Roh Kudus. Dalam menafsirkan angka tes ini, angka 1.0 atau -1.0 menunjukkan korelasi sempurna. Angka tersebut hendak menyatakan bahwa sepenuhnya latar belakang Gereja subjek menentukan pandangannya mengenai peran Roh Kudus atau sebaliknya. Angka 0,7 sampai dengan 0,9 menunjukkan korelasi yang kuat. Di bawah angka, 0,3 akan ditafsirkan menunjukkan lemahnya korelasi yang ada.

Dari tinjauan teoritis sebelumnya telah diuraikan bagaimana didapatkan pemahaman bahwa subjek yang datang dari latar belakang Gereja arus utama, maka lebih cenderung memandang Roh Kudus sebagai Allah yang menghibur, penasehat, dan pelindung. Sedangkan di kalangan Injili lebih ditekankan peran Roh Kudus sebagai yang menolong orang percaya lebih mengenal Allah dan kehendak-Nya yang dinyatakan melalui Alkitab. Sedangkan di kalangan Pentakosta dan Kharismatik. Ternyata, angka korelasi yang didapat dari Pearson Correlation Test adalah 0,076138432. Dalam hal ini, angka tersebut hendak menegaskan bahwa memang ada korelasi positif. Dalam pengertian lain, memang latar belakang Gereja responden yang diteliti sangat mempengaruhi pandangan mereka mengenai peran Roh Kudus. Namun, kekuatan keterkaitan atau pengaruhnya amat sangat rendah yakni di angka 0,1. Angka 0,1 tersebut berarti bahwa tidak terbukti secara sahih latar belakang seseorang yang berada dalam Gereja arus utama akan memiliki pandangan tentang Roh Kudus yang mencerminkan pandangan teologis denominasinya. Demikian juga latar belakang seseorang yang berada dalam Gereja Pentakostal atau Karismatik utama ternyata memperlihatkan kepelbagaian yang semestinya tidak terjadi. Oleh karena itu, klaim teoritik di atas semakin perlu ditinjau kembali. Bagaimanapun, gereja tidak mungkin bisa menutup diri dari tantangan kultural. Paul Challaghan mengatakan pengaruh kultural manusia yang hidup di era modern tentu saja akan sangat mempengaruhi hidup religiusitas dari masyarakat yang ada. ${ }^{177}$

Kedua, korelasi antara frekuensi asupan mengenai Roh Kudus melalui kotbah dan pandangan mengenai peran Roh Kudus. Ini mengukur apakah asupan mengenai Roh Kudus melalui khotbah menentukan pemahaman atau pandangan mengenai peran Roh Kudus di dalam hidup orang percaya. Hasil kajian di atas perlu diteliti lebih lanjut dengan

${ }^{177}$ Paul Challaghan, "Cultural Challenges to Faith: A Reflection on the Dynamics of Modernity," Journal Church, Communication and Culture, Vol. 2, Issue 1 (April 2017): 25-40. 
menelusuri apakah asupan pengajaran yang umumnya diselenggarakan lewat khotbah mengenai Roh Kudus menentukan pemahaman atau pandangan mengenai peran Roh Kudus di dalam hidup orang percaya. Sewajarnya, semakin intens masukan tentang Roh Kudus di dalam Gereja arus utama, semakin warganya memahami peran Roh Kudus sebagai Allah yang ada di dalam diri orang percaya, mengawal, menghibur, menguatkan, dan memberi karunia serta hal lain, namun yang terutama adalah sebagai Allah yang memungkinkan orang percaya mengalami transformasi nyata dalam statusnya sebagai manusia baru. Dan, jika dilihat dari teologi Roh Tuhan, seperti diterangkan oleh sebagai perbandingannya, di kalangan Pentakosta dan Kharismatik semestinya asupan yang ada membuat mereka memandang baptisan dalam Roh sebagai pemberi karunia dan kalangan Injili lebih memandang Roh Kudus berperan dalam menolong manusia memahami Firman Tuhan dan Diri-Nya.

Peneliti menganjurkan agar para pelayan Tuhan di gereja manapun untuk memberikan fokus perhatian yang lebih baru mengenai tidak adanya satu titik konvergensi antara tradisi historis, teologi dan pujian ataupun penyembahan di dalam gereja manapun hari ini. Artinya, seperti penjelasan dari Joseph K. Byrd homiletika gereja dalam pelayanan komunal semakin saling mempengaruhi antara seluruh gereja yang ada saat ini. ${ }^{178} \mathrm{Hal}$ itu, maksudnya uji korelatif pada bagian ke dua ini, semakin terbukti bahwa angka korelasi yang didapat dari Pearson Correlation Test setelah dilakukan analisis adalah angka 0,042267409. Angka ini berada dalam kelompok yang rendah. Rendahnya angka tersebut hendak menyatakan bahwa walaupun ada korelasi positif antara frekuensi atau kualitas asupan pengajaran di dalam gereja dengan pandangan orang mengenai peran Roh Kudus, namun korelasinya rendah. Perlu dinyatakan secara terbuka bahwa tentu saja masih perlu dilakukan penelitian lebih lanjut di kemudian hari tentang darimana masyarakat Kristen memiliki pandangan mereka tentang peran Roh Kudus. Peneliti mengakui secara jujur bahwa pada penelitian awal ini, hal itu tidak ditelusuri.

Ketiga, korelasi antara latar belakang gereja dan pandangan mengenai fungsi baptisan dalam Roh. Ini mengukur baptisan dalam Roh dengan pemberian karuniakarunia pribadi yang digunakan dalam pelayanan. Dari pemaparan teoritis disimpulkan

${ }^{178}$ Joseph K. Byrd, "Pentecostal Homiletic: A Convergence of History, Theology, and Worship," dalam Lee Roy Martin, L.R. (ed.), Toward a Pentecostal Theology of Preaching (Cleveland, TN: CPT Pres, 2015), 270288. 
bahwa kalangan Pentakosta dan Kharismatik lebih mengaitkan baptisan dalam Roh dengan pemberian karunia-karunia pribadi yang digunakan dalam pelayanan. Ajaran ini dikenal sebagai jaringan spirit kaum Pentakosta secara global oleh Joel Robbins. ${ }^{179}$ Kalangan arus utama mungkin lebih memandang baptisan dalam Roh sebagai proses membawa seseorang ke dalam persekutuan orang percaya. Kalangan Injili akan memandang baptisan dalam Roh sebagai titik awal pertumbuhan iman atau proses pengkudusan diri.180 Angka korelasi yang didapat dari Pearson Correlation Test mengenai ke dua variabel di atas adalah 0,093379989. Angka ini menunjukkan bahwa memang ada korelasi positif. Angka tersebut hendak menjelaskan bahwa memang latar belakang gereja responden yang diteliti mempengaruhi pandangan mereka mengenai fungsi baptisan dalam Roh. Meskipun harus diakui bahwa kekuatan keterkaitan atau pengaruh pandangan tersebut sangat rendah (yaitu sekitar 0,1). Angka 0,1 tersebut hendak mengatakan secara tegas bahwa tidak terbukti bahwa latar belakang seseorang yang berada dalam Gereja-gereja Pentakostal atau Kharismatis akan memahami peran baptisan dalam Roh dan aspek-aspeknya seperti yang umumnya jadi ajaran di kalangan ini demikian juga dengan kalangan Gereja lain.

Keempat, korelasi antara latar belakang Gereja dan pandangan tentang pemisahan antara Baptisan dalam Roh dan baptisan Air. Ini mengukur prakiraan logis dari gereja arus utama dan Injili tentang baptisan air dan baptisan dalam Roh. Secara teoritik diketahui bahwa responden yang berasal dari gereja arus utama memandang bahwa baptisan air dan baptisan dalam Roh merupakan hal yang menyatu dan sama. Ketika baptisan air dilakukan maka saat bersamaan baptisan dengan Roh juga terjadi. Fungsi keduanya adalah tanda dan meterai peristiwa keselamatan atau penebusan dalam Kristus atau kehidupan baru. Hal ini juga akan menjadi pandangan subjek dari kalangan Injili. Namun, bagi sebagian besar kalangan Pentakostal dan Karismatik memisahkan dan membedakan baptisan air dan baptisan dalam Roh. Baptisan air dikaitkan dengan penebusan atau titik balik hidup sebagai manusia baru. Kemudian baptisan dalam Roh akan dipahami berbeda-beda. Sebagai tahap selanjutnya untuk orang menjalani hidup

179 Joel Robbins, "Pentecostal Networks and the Spirit of Globalization On the Social Productivity of Ritual Forms,” Berghahn Journals: Social Analysis, Vol. 53, Issue 1 (Spring 2009):55-66.

${ }^{180}$ Mark A. Noll, David William Bebbington, George A. Rawlyk, Evangelicalism: Comparative Studies of Popular Protestantism in North America, the British Isles, and Beyond 1700-1900 (Oxford, UK: Oxford University Press, 1994). 
baru, penyucian, pertumbuhan iman, Gereja Pentakostal dan Karismatik melakukan pelayanan, menerima karuna-karunia, dan sebagainya. Meskipun saat ini, sebagai tambahan informasi, terdapat perhatian serius untuk meninjau kembali hal-hal yang diketahui secara umum tersebut seperi pernah dilakukan oleh Karen Murphy. ${ }^{181}$ Apalagi setelah dilakukan uji korelasi dilakukan menunjukkan hal lain. Korelasi tersebut sangat lemah yaitu -0,034728757 bahkan arahnya tidak positif. Angka tersebut hendak menjelaskan bahwa ada kemungkinan besar pandangan seseorang tentang fungsi baptisan dalam Roh justru menentukan pilihannya bergabung ke Gereja aliran seperti apa.

Kelima, korelasi antara pandangan mengenai pemisahan peran Roh Kudus dan fungsi Baptisan dalam Roh. Bagaimanapun, pengajaran gereja tentang ini pada umumnya dirujuk dari Alkitab khususnya dalam Teologi Perjanjian Baru yang dikonstruksi dari kitab Kisah Para Rasul dan Korintus. Dengan demikian, memang tidak salah jika F.F. Bruce ataupun Jack Levison menyatakan bahwa teologi Roh Kudus dari gereja mengenai peran Roh Kudus dan fungsi Baptisan dalam Roh itu lebih banyak merupakan interpretasi pembaca atas Manifestasi Roh Kudus yang direkam dalam Kisah Para Rasul dan juga dalam surat Paulus dalam kitab Korintus yang memang menjelaskannya. ${ }^{182}$ Tetapi, pada bagian ini, penulis mengukur peran Roh Kudus dengan fungsi baptisan dalam Roh. Setelah dilakukan Pearson Correlation Test apakah pandangan mengenai peran Roh Kudus terkorelasi dengan pandangan mengenai fungsi baptisan dalam Roh? Bagaimana arah korelasinya? Ternyata, angka korelasi yang ditemukan ialah -0,049368983. Angka tersebut hendak menunjukkan secara lugas bahwa korelasinya bersifat negatif dan juga dengan angka yang sangat rendah.

Keenam, korelasi antara latar belakang gereja dan asupan dari gereja tentang ajaran mengenai Roh Kudus di dalam kotbah. Ini mengukur frekuensi kotbah tentang

${ }^{181}$ Murphy mencatat bidang-bidang di mana dialog doktrinal telah berkembang sejak permulaannya hingga sekarang. Dia membongkar kesamaan yang mengikat umat Katolik dan Pentakosta serta meneliti divergensi teologis dan tantangan dialog. Sementara pendekatan Katolik menjadi seorang Kristen dari perspektif sakramental, sebagian besar Pentakosta berpikir tentang inisiasi Kristen dalam istilah-istilah non-sakramental, atau konversi, kenyataan, yang menumbuhkan ketegangan yang sedang berlangsung antara kedua tradisi. Murphy mengungkapkan bagaimana umat Katolik dan Pentakosta berupaya untuk mengatasi dikotomi ini dengan menghormati spiritualitas dan pengalaman sebagai bagian integral dari perjumpaan ekumenis. Lihat, Karen Murphy, Pentecostals and Roman Catholics on Becoming a Christian: Spirit-Baptism, Faith, Conversion, Experience, and Discipleship in Ecumenical Perspective (Leiden: Brill, 2018).

182 F.F. Bruce, "The Holy Spirit in the Acts of the Apostles", Interpretation: A Journal Bible and Theology, Vol. 27, Issue 2, (April 1973) 166-183; Jack Levison, "The Holy Spirit in 1 Corinthians," Interpretation: A Journal Bible and Theology, Vol. 72 Issue: 1 (January 2018): 29-42. 
pengalaman Roh Kudus dari berbagai aliran yang lain. Secara teoritik dikenal klaim kaum Pentakosta. Mereka merasa berhak untuk menyatakan ciri khas yang lama kelamaan membentuk identitas kekristenan, seperti penjelasan dari. ${ }^{183}$ Dengan klaim itu diketahui bahwa gereja-gereja Pentakosta atau Karismatik memiliki frekuensi khotbah yang lebih tinggi membahas pengalaman dengan Roh Kudus dibandingkan aliran yang lain. Namun, ternyata setelah dilakukan Pearson Correlation Test menunjukkan angka -0,034728757. Angka ini secara tegas hendak menunjukkan korelasi negatif antara latar belakang Gereja dengan intensitas atau frekuensi asupan melalui kotbah. Dengan angka itu dapat diketahui bahwa justru kalangan Pentakostal atau Karismatik memiliki frekuensi ajaran mengenai Roh Kudus yang kurang banyak di dalam khotbah dibandingkan kalangan lain. Angka korelasinya terbilang rendah yaitu 0,1 . Temuan ini menjadi menarik untuk ditindaklanjuti. Apakah hal ini menunjukkan adanya pertentangan teoritik dengan kenyataan setiap hari? Atau apakah terdapat faktor lain yang lebih riil yaitu kalangan Pentakostal atau Karismatik sedang mengalami pergeseran penekanan pengajaran internal lewat khotbah mimbar dengan topik-topik lebih luas dari topik tradisional mereka? Ini tentu saja anomali yang membutuhkan pendalaman. Penelitian lanjutan dengan subjek lebih banyak dan beragam dari kalangan ini jelas masih sangat diperlukan.

Ketujuh, korelasi antara asupan mengenai Roh Kudus melalui kotbah dan pandangan mengenai fungsi baptisan khususnya, apakah ada satu atau dua macam baptisan. Bagian ini hendak mengukur peran khotbah akan pembentukan pemahaman atau pandangan mengenai fungsi baptisan Roh khususnya keberbedaan fungsi baptisan air dan baptisan dalam Roh. Secara teoritik dipahami bahwa asupan pengajaran mengenai Roh Kudus melalui khotbah akan menentukan pemahaman atau pandangan mengenai fungsi baptisan, khususnya apakah berbeda fungsi baptisan air dan baptisan dalam Roh. Semakin sering ada atau semakin intens terjadinya masukan mengenai Roh Kudus, maka semakin orang Kristen akan semakin memahami peran Roh Kudus serta baptisan berfungsi sebagai titik balik perubahan atau pertumbuhan terus menerus serta karunia-karunia yang diberikan bagi orang percaya. Hal itu sejalan dengan penjeasan dari Yannick Fer habitus kaum Pentakosta bahwa pengajaran gereja bukan hanya mampu membentuk otoritas institusional tetapi juga kehidupan sosiologis jemaat dalam

183 Opoku Onyinah, "The Movement of the Spirit Around the World in Pentecostalism," Transformation, Vol. 30, No. 4 (October 2013): 273-286. 
kehidupan nyata. ${ }^{184}$ Namun, ternyata setelah dilakukan Pearson Correlation Test menunjukkan angka 0,104596898. Angka ini menunjukkan angka yang rendah. Dengan demikian maka benar ada korelasi positif antara frekuensi atau kualitas asupan dengan pandangan orang mengenai baptisan dalam Roh, namun korelasinya sangat rendah. Peneliti harus terbuka untuk mengetahui bahwa untuk hal itu masih harus dikerjakan penelitian lebih lanjut di kemudian hari. Darimana mereka memiliki pandangan mereka tentang Baptisan dalam Roh yangmana pada penelitian awal ini memang tidak ditelusuri.

Kedelapan, korelasi pemahaman atau perhatian subjek pada ayat-ayat populer dari Perjanjian Baru yang terkait Roh Kudus dan Baptisan dalam Roh dengan pemahaman mengenai peran-Nya. Bagian ini dimaksudkan untuk mengukur sejauh manakah pengenalan responden mengenai ayat-ayat Perjanjian Baru mengenai Roh Kudus. Sebelumnya dari kajian teoritis dan pengamatan diketahui bahwa semestinya, warga Gereja-gereja Pentakosta dan Kharismatik akan memiliki pengenalan mengenai ayat-ayat tersebut. Hal itu terjadi dengan asumsi bahwa ciri khas dari mereka memang terkait langsung mengenai Roh Kudus dan Baptisan dalam Roh dengan pemahaman mengenai peran-Nya. Berkebalikan dari teori, ternyata setelah dilakukan Pearson Correlation Test, korelasi antara pengenalan terhadap ayat-ayat Perjanjian Baru tersebut dengan pemahaman mengenai peran Roh Kudus masih rendah yaitu 0,15643617. Namun, korelasi yang ada dengan salah satu ayat, yaitu Kisah Rasul 1:4-5 yaitu peristiwa pentakosta dengan pemahaman mengenai peran Roh Kudus lebih tinggi yaitu, 0,219565, walaupun masih tergolong rendah dalam kerangka analisis Person.

Lewat analisis pada bagian ke delapan ini dapat disimpulkan secara umum bahwa tingkat korelasi antara latar belakang denominasi gereja responden yang diteliti dengan pandangan-pandangan mereka mengenai peran Roh Kudus, fungsi baptisan, atau beberapa jenis baptisan amat rendah bahkan mendekati angka 0. Juga, terbukti rendahnya korelasi antara pemahaman atau pandangan subjek mengenai peran Roh Kudus dengan pemahamannya mengenai fungsi baptisan dan apakah ada beda antara baptisan air dan baptisan dalam Roh.

Mengenai kaitan antara peran Roh Kudus di dalam Gereja, pribadi, dan semesta, apa yang disampaikan Moltmann seperti dijelaskan di bagaian awal, tidak kentara pada

${ }^{184}$ Yannick Fer, "The Holy Spirit and the Pentecostal Habitus: Elements for a Sociology of Institution in Classical Pentacostalism," Nordic Journal of Religion and Society, Vol. 23, Issue 2 (2010): 157-176. 
responden hasil penelitian yang ada. Sangat sedikit responden lebih tepatnya hanya 5 orang yang menyatakan secara tegas bahwa Roh Kudus hadir di dalam seluruh ciptaan Allah. Dapat dicatat bahwa salah satu tingkat korelasi yang lebih tinggi dari korelasikorelasi yang diuji adalah pengenalan responden akan Kisah Rasul 1:4-5 yaitu peristiwa Pentakosta dengan pandangan mereka mengenai peran Roh Kudus. Pertanyaan terbesar adalah bagaimana menyimpulkan temuan tersebut? Apakah sesungguhnya ada yang dinamakan dnegan paradox kaum Pentakosta seperti yang pernah dikatakan oleh G. J. Hocking? ${ }^{185}$ Beberapa hal ini dapat jadi kemungkinan untuk ditelusuri lebih lanjut. Oleh karena itu, hal itu dapat disusur dari Perjanjian Baru seperti berikut ini.

\section{Pemahaman Ayat-Ayat Populer Perjanjian Baru}

Hasil penelitian awal di atas menunjukkan bahwa, tidak ada korelasi yang kuat antara latar belakang denominasi subjek dengan pemahaman mereka mengenai peran Roh Kudus dan fungsi baptisan dalam Roh, serta lokasi kehadiran Roh Kudus di masa kini. Juga dari straight tabulasi menunjukkan bahwa, perhatian mereka pada ayat-ayat Perjanjian Baru tentang Roh Kudus dan frekuensi asupan mengenai Roh Kudus melalui kotbah tidak terkorelasi dengan kuat dengan pemahaman-pemahaman di atas dan latar belakang denonominasi mereka.

Yang penting untuk diperhatikan lebih lanjut ialah bagaimana menjelaskan gejala di atas. Salah satu kemungkinan yang ada bersumber pada teks-teks di dalam Perjanjian Baru yang terkait Roh Kudus. Bila membahas mengenai Roh Kudus dan baptisan dalam Roh, Injil Sinoptik memuat teks-teks yang popular. Demikian juga dengan Injil Yohanes dan tulisan-tulisan lain di Perjanjian Baru, khususnya surat-surat yang terkait dengan Rasul Paulus. Dengan demikian, ada dasar untuk mengakui pemaparan dari Richard Mayhue, bahwa ajaran Perjanjian Baru atas Roh Tuhan merupakan persoalan kedekatan hubungan sipritualitas secara mendalam yang bisa direfleksikan oleh gereja. ${ }^{186}$ Dalam

${ }^{185}$ Paradoks Pentakosta mengeksplorasi sejarah dan kebangkitan gerakan keagamaan baru yang disebut Pentakosta. Menggambarkan situasi bagaimana para saksi mata saksi, artikel surat kabar hari itu, dan sumbersumber lain yang sudah lama terlupakan, penulis G. J. Hocking menyusun sejarah yang akurat dari gerakan sampai hari ini yang mana semakin ditemukan hal-hal yang makin bergeser (untuk menghindari kata menyimpang) dari inti ajaran awal. Paradoks Pentakosta bertanya, apakah peristiwa-peristiwa Pentakosta modern ini fakta, fiksi, atau fenomena nyata? Lewat bukunya, ia mengkritisi kelompok besar ini, apa dan bagaimana selanjutnya fenomena Pentakostalisme? Lihat, G. J. Hocking, The Pentecostal Paradox (Eugene, Oregon: Wipf and Stock, 2019).

${ }^{186}$ Richard Mayhue, Spiritual Intimacy (Wheaton, Il: Victor Books, 1990), 8,10, 170; Richard Mayhue, Seeking God: How to Develop an Intimate, Spiritual Relationship (Fearn, Scotland: Christian Focus Publications, 2000). 
Injil Markus pasal 1 ayat 6 sampai dengan 8 dipaparkan bahwa, Yohanes Pembaptis memakai jubah bulu unta dan ikat pinggang kulit, dan makanannya belalang dan madu hutan. Dan ia memberitakan bahwa, "Sesudah aku akan datang Ia yang lebih berkuasa dari padaku; membungkuk dan membuka tali kasut-Nyapun aku tidak layak. Aku membaptis kamu dengan air, tetapi Ia akan membaptis kamu dengan Roh Kudus."

Dalam bahasa Yunani kalimat terakhir dituliskan ego baptisa humas hudati auto de baptisei humas en Pneumati. Kata preposisi "en" yang dipergunakan 2775 kali di Perjanjian Baru. Kata ini diterjemahkan sebagai "di dalam” atau "dengan." Dalam Injil Sinoptik lainnya, yaitu Matius 3: 11 dituliskan "Aku membaptis kamu dengan air sebagai tanda pertobatan, tetapi Ia yang datang kemudian dari padaku lebih berkuasa dari padaku dan aku tidak layak melepaskan kasut-Nya. Ia akan membaptiskan kamu dengan Roh Kudus dan dengan api.” Di sini baptisan Yohanes pembaptis dengan air dikaitkan sebagai tanda pertobatan dan baptisan Roh dilakukan oleh Yesus Kristus.

Sedangkan di dalam Injil Lukas, kehadiran Kristus dikaitkan dengan berbagai nubuatan-nubuatan. Nubuatan-nubuatan itu dialami oleh Zakaria dan Elisabet. Kaitan antara Roh Kudus dan Kristus dipaparkan dalam Luk 1:41-43 "Dan ketika Elisabet mendengar salam Maria, melonjaklah anak yang di dalam rahimnya dan Elisabetpun penuh dengan Roh Kudus, lalu berseru dengan suara nyaring: "Diberkatilah engkau di antara semua perempuan dan diberkatilah buah rahimmu. Siapakah aku ini sampai ibu Tuhanku datang mengunjungi aku?" Kehadiran Roh Kudus terkait dengan zaman baru, yaitu kehadiran Mesias dan merupakan kelanjutan dari masa perjanjian lama. Hal ini lebih tajam dipaparkan dalam baptisan Yesus oleh Yohanes pembaptis sebagaimana dipaparkan di dalam Lukas 3:22. Walaupun Lukas dan Yohanes sama-sama menekankan kaitan erat antara Roh Kudus dan Kristus, namun Lukas lebih menekankan kaitan-Nya sebagai kelanjutan hidup umat perjanjian di Perjanjian Lama sedangkan Yohanes menekankan bahwa, melalui pelayanan Kristus yang penuh Roh Kudus, banyak orang sudah mendapatkan gambaran masa depan yang seharusnya walaupun belum hidup di dalam-Nya. Hanya setelah penyaliban dan kebangkitan Kristus terjadi, mereka dapat sepenuhnya mengalami hidup di dalam Roh Kudus.

Masih sekaitan dengan penjelasan di atas, di dalam kaca mata awam, Injil Yohanes 1:33 diingat: "Dan akupun tidak mengenal-Nya, tetapi Dia, yang mengutus aku untuk membaptis dengan air, telah berfirman kepadaku: Jikalau engkau melihat Roh itu turun ke atas seseorang dan tinggal di atas-Nya, Dialah itu yang akan membaptis dengan Roh 
Kudus." Sedangkan, dalam tulisan karya Lukas, yaitu Kisah Rasul 1: 4 dan 5 terdapat catatan "Pada suatu hari ketika Ia makan bersama-sama dengan mereka, Ia melarang mereka meninggalkan Yerusalem, dan menyuruh mereka tinggal di situ menantikan janji Bapa, yang-demikian kata-Nya-" telah kamu dengar dari pada-Ku. Sebab Yohanes membaptis dengan air, tetapi tidak lama lagi kamu akan dibaptis dengan Roh Kudus." Jelas isi ayat ini berbeda dengan apa yang disampaikan dalam Injil Yohanes dan Injil Sinoptik lainnya (Matius dan Markus). Bila di dalam Injil Yohanes dan Sinoptik disebutkan Kristus sebagai sosok yang akan melakukan baptisan dalam Roh, di dalam Kisah Rasul dicatat Kristus sendiri menunjukkan bahwa, akan ada baptisan dengan Roh Kudus sesudah kepergian-Nya kembali ke surga.

Sementara dalam ajaran Kisah Rasul: Kemudian, bagian yang populer dan diingat orang Kristen dari berbagai kalangan adalah Kisah Rasul 2:1-4 "Ketika tiba hari Pentakosta, semua orang percaya berkumpul di satu tempat. Tiba-tiba turunlah dari langit suatu bunyi seperti tiupan angin keras yang memenuhi seluruh rumah, di mana mereka duduk; dan tampaklah kepada mereka lidah-lidah seperti nyala api yang bertebaran dan hinggap pada mereka masing-masing. Maka penuhlah mereka dengan Roh Kudus, lalu mereka mulai berkata-kata dalam bahasa-bahasa lain, seperti yang diberikan oleh Roh itu kepada mereka untuk mengatakannya."

Kemudian, surat-surat Paulus: Bila kita meninjau surat-surat Paulus, terkesan bahwa, sosok ini mengaitkan Roh Kudus dengan berbagai-bagai situasi dan topik. Walaupun para ahli menyebutkan beberapa cara mensistematisasi apa yang Paulus yakini, hal itu sangat kompleks. Namun, Turner, seorang pakar memberikan beberapa petunjuk mengenai pneumatologi Paulus. Antara lain, Roh Kudus memberikan karunia pada persekutuan orang percaya, sehingga kuasa keselamatan mereka nyata. Roh Kudus juga memulai kehidupan baru orang percaya dan terus memimpin serta mengawal prosesnya terutama dalam melawan kedagingan (lihat Galatia 3, 5, dan 6 serta Roma 8). Bahkan, Roh Kudus memperbaharui persekutuan orang percaya. Aspek-aspek itulah yang khas dalam ajaran Paulus dibandingkan apa yang ada di dalam kitab Injil Sinoptik dan injil Yohanes. ${ }^{187}$

Perlu juga ditekankan di sini bahwa memang masih banyak ayat-ayat lainnya.

${ }^{187}$ Max Turner, The Holy Spirit and Spiritual Gifts Then and Now (Carlisle, Cumbria, UK: Paternoster Press, 1996), 131-132. 
Namun, seorang yang membaca Alkitab sebagaimana catatan-catatan dalam Perjanjian Baru tersebut sebagai mana tampil di atas (as-it-is), cenderung mudah mentafsirkan bahwa, ada dua jenis baptisan yang tersedia bagi orang yang Tuhan pilih. Pertama, ada baptisan air untuk kelahiran baru yang diperoleh karena pengampunan dosa melalui karya penebusan Kristus dan kedua, ada baptisan dalam Roh atau baptisan Roh untuk orang yang sudah mengalami penebusan itu. Bagi yang meyakini perbedaan di antara kedua baptisan itu, maka fungsi baptisan Roh ini ditafsirkan secara berbeda-beda. Ada yang menafsirkan bahwa baptisan Roh terkait entah dengan proses pertumbuhan iman. Ada pula yang mengaitkannya dengan proses pengkudusan. Bahkan ada yang menyatakan bahwa baptisan dalam roh itu diberikan agar orang siap menjadi mitra Allah melaksanakan misi-Nya di dalam dunia, atau proses menuju kepenuhan anugerah Roh Kudus. ${ }^{188}$

Selain itu, teks-teks di atas membuka ruang untuk perbedaan tafsiran di dalam hidup spiritual praktis orang Kristen, yaitu istilah "Kamu." Pertama, apakah baptisan dalam Roh itu terutama merupakan suatu pengalaman pribadi atau pengalaman komunal. Hal ini terjadi karena, konteks kata-kata tersebut disampaikan adalah ketika murid-murid berada bersama dan tidak disampaikan pada satu orang saja. Walaupun sebagai penelitian awal, sejauh ini memang subjek dipilih berdasarkan avaliabilitas dan bukan random, namun juga berdasarkan kluster: Gereja Injili, Pentakosta/Karismatik, dan Gereja Arus Utama, namun bila hasil yang didapatkan melalui Pearson Correlation Test adalah tepat, maka kajian di atas terkait ayat-ayat Perjanjian Baru yang populer dapat menjadi penjelasan mengapa tidak terjadi korelasi positif yang kuat antara latar belakang Gereja subjek yang diteliti dengan asupan yang diterimanya dari Gereja mengenai Roh Kudus melalui kotbah, perhatiannya tentang ayat-ayat yang terkait Roh Kudus dan pandangan mengenai peran Roh Kudus dan fungsi baptisan serta pemahamannya mengenai lokasi kehadiran Roh Kudus kini.

\section{Pembinaan Gereja Terkait Roh Kudus}

Gereja saat ini perlu dibawa kepada praksis iman yang ada kaitannya dengan teologi Roh Kudus yang bukan dalam artian historis maupun ilmu teologis belaka.

${ }^{188}$ T. John Padwick, "The Spirit Alone": Writing the Oral Theology of a Kenyan Independent Church," Transformation: An International Journal of Holistic Mission Studies, Vol. 35, Issue 1 (April 2018): 15-29. 
Memang, Martin Lindhardt dan kolega pernah mengajak gereja untuk melaksanakan keberimanan warga gereja berkaitan dengan pengalaman-pengalaman Roh Kudus. ${ }^{189}$ Sayang sekali memang, ketika ia dan kolega berkata demikian, hal itu lebih terfokus kepada masyarakat Kristen Pentakosta maupun Kharismatis. Artinya, ia tidak ada upaya melibatkan gereja-gereja arus utama maupun kaum Injili di sana. Ini merupakan persoalan klasik di dalam gereja sejak gereja modern mula-mula yang masih terjadinya segregasi. Itulah alasannya, pada bagian ini, peneliti hendak menekankan adanya refleksi ajaran gereja tentang Roh Kudus dari hasil analisis yang dapat dilakukan gereja secara lebih intensif. Bagaimanapun adanya kekurangan-kekurangan di dalamnya, tak terpungkiri, seperti kata David W. Faupel, gerakan Pentakosta merupakan salah satu gerakan kegamaan Kristen yang paling cepat berkembang secara global. ${ }^{190}$ Bahkan, Rachel Muers mengakatan suara dan lingkungan gerakan itu semakin di dengar dan memiliki ruang yang luas di antara Kristen secara global. ${ }^{191}$ Peneliti mengatakan demikian, justru bukan hendak menekankan atau mengimitasi ciri khas dari kelompok tersebut tetapi ajaran Roh Kudus yang memang kerap dikhotbahkan secara lebih intensif dibandingkan denominasi lain.

Seperti dijelaskan bahwa ternyata dari temuan penelitian di atas menunjukkan bahwa frekuensi khotbah-khotbah tidak cukup dalam memberikan paparan atau sentuhan yang utuh serta mendalam bagi umat. Demikian juga asal Gereja dari responden yang diteliti tidak berkorelasi kuat dengan frekuensi asupan-asupan pengajaran lewat khotbah serta dengan pandangan-pandangan responden yang diteliti. Dalam hal ini dua kemungkinan dapat terjadi. Pertama, apapun aliran Gereja yang subjek yang diteliti, pendalaman paham dan pengalaman dengan Roh Kudus dan baptisan dalam Roh tidak cukup didapatkan secara lengkap ataupun utuh. Dengan demikian, tidak heran absennya korelasi atau hubungan yang kuat antara latar belakang Gereja asal subjek dengan kepelbagaian pandangannya mengenai peran Roh Kudus di dalam hidup dan fungsi atau makna baptisan dalam Roh seperti yang dalam tinjauan teoritis kita harapkan. Khususnya, Gereja-gereja Pentakosta dan Karismatis, mereka diharapkan lebih

${ }^{189}$ Martin Lindhardt (ed), Practicing the Faith: The Ritual Life of Pentacostal-Charismatic Christians (New York and Oxford: Berghahn Books, 2011).

${ }^{190}$ David W. Faupel, The Everlasting Gospel: The Significance of Eschatology in the Development of Pentecostal Thought (Blandford Forum, UK: Deo Publishing, 2008).

191 Rachel Muers, "The Holy Spirit, the Voices of Nature and Environmental Prophecy," Scottish Journal of Theology, Vol. 67, Issue 3 (August 2014): 323-339. 
menekankan frekuensi asupan mengenai Roh Kuds melalui kotbah dan menyatukan pemahaman warga mengenai pengalaman mereka mengenai Roh Kudus.

Kemungkinan kedua adalah, apapun aliran Gereja seseorang, ajaran tentang Roh Kudus entah disampaikan sepenggal-sepenggal atau dibiarkan bervariasi. Bila hal ini benar kemungkinan penyebabnya adalah tidak cukup keprihatinan, kesadaran, dan komitmen mengenai pentingnya peran Roh Kudus dalam hidup pribadi, Gereja, atau masyarakat karena memang dimensi misteriNya membuat Ia tidak dibahas atau karena perhatian pada Kristologi lebih mendominasi perhatian umat Kristen di Indonesia. Memang, harus disebutkan bahwa untuk mendapatkan hasil yang lebih rinci, diperlukan studi lanjutan dengan jumlah subjek yang lebih besar dan berasal secara seimbang dari ketiga kalangan Gereja-gereja asal mereka. Akan tetapi, refleksi ini bukanlah melulu mengenai kerja-kerja ilmiah belaka, tetapi juga praksis, yaitu adanya penguatan ajaran tentang Roh Tuhan di dalam gereja dan kehidupan riil jemaat. Menarik untuk mempertimbangkan penjelasan dari Amos Yong, ketika ia mengusulkan agar gereja manapun mulai untuk memperluas ide-ide pekerjaan Roh Kudus yang lebih dinamis dan banyak memberi informasi pneumatologis tentang misi Kristen holistik untuk menjalani praktik misi di dunia pluralistik secara global. ${ }^{192}$

\section{Kesimpulan}

Sejauh ini hasil penelitian awal ini menunjukkan bahwa, Roh Kudus ialah teologi Roh Tuhan di dalam gereja meskipun berbeda dalam hal penekanannya berdasarkan bagaimana Roh dan ajaran mengenai hal itu dipersepsikan selama ini. Layak disebut persepsi masyarakat Kristen secara umum karena lewat uji empiris secara kuantitatif ditemukan ternyata tidak ada korelasi yang kuat antara latar belakang denominasi subyek yang diteliti dengan pandangan mereka tentang peran Roh Kudus. Suatu hal yang penting di dalam pneumatologi atau pengalaman intens kalangan Pentakosta dan Karismatik adalah sumbangsih yang kalangan ini dapat berikan pada kalangan Kristiani lainnya. Pertama, misteri dan Roh Kudus merupakan hal yang merupakan dimensi yang tidak dapat dilupakan dan membimbing orang-orang percaya untuk rendah hati serta mengenal batas keberadaannya. Kedua, proses transformasi setelah seorang menerima

192 Amos Yong, "Toward a Trinitarian Theology of Religions: A Pentecostal-Evangelical and Missiological Elaboration," International Bulletin of Mission Research, Vol. 40, Issue 4 (June 2016): 294-306. 
anugerah keselamatan atau penebusan di dalam Kristus adalah sesuatu yang bersifat universal. Dampak peran transformatif Roh Kudus sebagai pendidik, pelindung, penasehat, pemberi curahan kuasa, dan pembimbing di dalam proses ini tentunya harus terlihat di dalam hidup pribadi seorang percaya baik pada aspek nalar, afektif, dan kognitif serta kepekaan spiritual atau keintiman dengan-Nya. Dampak peran transformatif Roh Kudus di dalam hidup gereja juga harus dikenali, dipahami, dan dirumuskan secara praktis sehingga persekutuan orang percaya tidak menghambat pekerjaan-Nya. Dampak peran transformatif Roh Kudus di tengah seluruh ciptaan Allah juga perlu dikenali dan dirumuskan agar sebagai pribadi, keluarga, dan gereja, baik tujuan dan prosesnya didukung penuh sesuai dengan bagian yang dipercayakan pada orang percaya. Tentunya, untuk melanjutkan temuan dan kajian yang lebih mendalam lagi maka tetap diperlukan penelitian lanjutan dengan sampling yang lebih besar.

Gereja manapun mengetahui perihal Roh Kudus sebagai doktrin Kristen meskipun memang masih tidak mendapatkan perhatian yang selayaknya. Baik itu dalam peran-Nya, pandangan utuh mengenai fungsi Baptisan dalam Roh, serta pengenalan akan lokasi kehadiran-Nya di masa kini. Oleh karena itu, dengan tidak adanya korelasi yang kuat antara latar belakang denominasi subyek yang diteliti dengan pandangan mereka tentang peran Roh Kudus, maka tidaklah melebih-lebihkan agar gereja di Indonesia memikirkan kembali bukan hanya perbedaan persepsi atas ajaran Roh Kudus secara teologis internal gereja. Akan tetapi, manifestasinya juga terbuka pada kesempatan pekerjaan Roh di dalam ruang sosial yang lebih luas demi terjadinya perubahan keagamaan yang berimpak pada bangsa, melebihi gerakan tradisional agama, seperti pernah terjadi di kalangan Protestan Amerika paska Perang Sipil 1865-1915. Di mana gerakan Roh Kudus di ruang sosial, atau "Injil sosial," demikian pernah dinamai oleh para sejarawan dunia, meluas hingga meredanya Peran Dunia I dan II terus berkembang hingga tahun 1960-an sebagaimana dituturkan oleh Ronald C. White, Charles H. Hopkins. 193 "Injil sosial” yang tidak boleh mengecilkan ataupun melalaikan peran Roh Kudus tersebut begitu saja di Indonesia semestinya bisa dibawa melangkah keluar dari gereja-gereja untuk terlibat dalam perbaikan kekuatan politik, sosial, dan ekonomi bangsa.

193 Charles H. Hopkins, The Rise of the Social Gospel in American Protestantism, 1865-1915 (New Heaven, CT: Yale University, 1967), 113-114; Ronald C. White, Charles H. Hopkins, The Social Gospel: Religion and Reform in Changing America (Philadelphia: Temple University Press, 1976). 
Dengan mendasarkan pada temuan empiris, gereja-gereja di Jabodetabek meskipun berbeda organisasi dan doktrin ternyata tidak korelatif dengan peran Roh Kudus, maka tulisan ini mengusulkan perlu memasukkan studi persepsi masyarakat Kristen dalam bidang teologi, dan juga Pentakostalisme. Studi persepsi, dalam bidang ilmu-ilmu sosial dan humaniora dengan berbagai metode, paling sering digunakan ketika seseorang mencoba mencari tahu bagaimana orang memahami atau merasakan tentang situasi atau lingkungan mereka. Mereka digunakan untuk menilai kebutuhan, menjawab pertanyaan, memecahkan masalah, menetapkan garis dasar, menganalisis tren, dan memilih tujuan. Alasan utama mengapa melakukan survei adalah untuk mendapatkan umpan balik tentang kinerja masa lalu, saat ini, dan atau untuk mendapatkan informasi untuk arah masa depan. ${ }^{194}$ Namun, itu dapat digunakan jauh lebih dari sekadar cara untuk mengumpulkan informasi tetapi juga bisa digunakan dalam bidang teologi Kristen.

Tak bisa ditutupi, selama ini banyak konflik dan perpecahan di dalam gereja di Indonesia. Adalah sangat memprihatikan ketika itu terjadi, tetapi lebih ironis lagi karena konflik dan perpecahan secara umum lebih sering dilihat dan diterima begitu saja akibat dari adanya perbedaan doktrinal. Studi ini telah membantah itu. Di sinilah tampak sumbangsih keilmiahan dari tulisan ini. Sehingga dengan demikian, studi ini telah menunjukkan salah satu cara untuk menemukan cara untuk mengatasinya yakni dengan melakukan studi persepsi.

\section{Kepustakaan}

Atetwe, Ahono Telesia, Jairo Peter Aloka, Calleb Owino Gudo. "Influence of Efficacy Expectation on Mathematics Achievement among Students in Secondary Schools in Kenya." International Journal of Education and Research, Vol. 6 No. 8 (August 2018):141-151.

Bennett, Zoe, Elaine Graham, Stephen Pattison, Heather Walton. Invitation to Research in Practical Theology. London and New Yok: Routledge, 2018.

Bergmann, Sigurd. Creation Set Free: The Spirit as Liberator of Nature. Grandrapids, Michigan and Cambridge, UK: Wm. B. Eerdmans Publishing Company, 2005.

Bruner, Frederick Dale. A Theology of the Holy Spirit: The Pentecostal Experience and the New Testament Witness. Eugene, Oregon: Wipf and Stock Publishers, 1997.

${ }^{194}$ Lee Jussim, Social Perception and Social Reality: Why Accuracy Dominates Bias and Self-Fulfilling Prophecy (New York: Oxford University Press, 2012), 293. 
Bruce, F.F. "The Holy Spirit in the Acts of the Apostles." Interpretation: A Journal Bible and Theology, Vol. 27, Issue 2 (April 1973): 166-183.

Byrd, Joseph K. "Pentecostal Homiletic: A Convergence of History, Theology, and Worship," dalam Lee Roy Martin, L.R. (ed.). Toward a Pentecostal Theology of Preaching. Cleveland, TN: CPT Pres, 2015.

Cartledge, Mark J. Practical Theology: Charismatic and Empirical Perspectives. Eugene, Oregon: Wipf \& Stock, 2012.

Challaghan, Paul. "Cultural Challenges to Faith: A Reflection on the Dynamics of Modernity." Journal Church, Communication and Culture, Vol. 2, Issue 1 (April 2017): 25-40.

Chan, Simon. Pentecostal Theology and the Christian Spiritual Tradition Reprinted. Sheffield, UK: Sheffield Academic, 2003.

Dayton, Donald. Theological Roots of Pentecostalism. Grand Rapids, Michigan: Baker Academic, 1987.

Faupel, David W. The Everlasting Gospel: The Significance of Eschatology in the Development of Pentecostal Thought. Blandford Forum, UK: Deo Publishing, 2008.

Fer, Yannick. "The Holy Spirit and the Pentecostal Habitus: Elements for a Sociology of Institution in Classical Pentacostalism." Nordic Journal of Religion and Society, Vol. 23, Issue 2 (2010): 157-176.

Hocking, G. J. The Pentecostal Paradox. Eugene, Oregon: Wipf and Stock, 2019.

Hopkins, Charles H. The Rise of the Social Gospel in American Protestantism, 1865-1915. New Heaven, CT: Yale University, 1967.

Jussim, Lee. Social Perception and Social Reality: Why Accuracy Dominates Bias and SelfFulfilling Prophecy. New York: Oxford University Press, 2012.

Karkkainen, Veli-Matti. Pneumatology: The Holy Spirit in Ecumenical, International, and Contextual Perspective Second Edition. Grand Rapids, Michigan: Baker Academic, 2018.

Kim, Kirsteen. The Holy Spirit in the World: A Global Conversation. New York: Orbis Books, 2007.

Lanz, Eddy. Seven Truths about the Holy Spirit. Rawalpindi, Pakistan: GNU Free Documentation License, 2013.

Levison, Jack. "The Holy Spirit in 1 Corinthians." Interpretation: A Journal Bible and Theology, Vol. 72 Issue 1 (January 2018): 29-42.

Lindhardt, Martin (ed). Practicing the Faith: The Ritual Life of Pentacostal-Charismatic Christians. New York and Oxford: Berghahn Books, 2011.

Macchia, Frank D. Jesus the Spirit Baptizer: Christology in Light of Pentecost. Grand Rapids, Michigan: W.B. Eerdmans Publishing 2018. Justified in the Spirit: Creation, Redemption, and the Triune God. Grand Rapids, Michigan: W.B. Eerdmans Publishing 2010. 
"Baptized in the Spirit: Toward a Global Theology of Spirit Baptism," dalam Veli Matti Karkainnen (ed). The Spirit in the World: Emerging Pentacostal Theologies in Global Context. Grand Rapids, Michigan: W.B. Eerdmans Publishing 2009.

. Baptized in the Spirit: A Global Pentecostal Theology. Grand Rapids, Michigan: Zondervan, 2006.

Hovat, Marian. Augustine and the Seashell, https://www.traditioninaction.org/religious/h065rp.Shell.html. Diunduh 21

September, 2019.

Mayhue, Richard. Spiritual Intimacy. Wheaton, Il: Victor Books, 1990.

Seeking God: How to Develop an Intimate, Spiritual Relationship. Fearn, Scotland: Christian Focus Publications, 2000.

Muers, Rachel. "The Holy Spirit, the Voices of Nature and Environmental Prophecy." Scottish Journal of Theology, Vol. 67, Issue 3 (August 2014): 323-339.

Murphy, Karen. Pentecostals and Roman Catholics on Becoming a Christian: Spirit-Baptism, Faith, Conversion, Experience, and Discipleship in Ecumenical Perspective. Leiden: Brill, 2018.

Moltmann, Jurgen. God in Creation: A New Theology of Creation and the Spirit of God Translated by Margaret Kohl. London: SCM Press Ltd, 1985.

- The Spirit of Life: A Universal Affirmation Translated by Margaret Kohl. Minneapolis: Fortress Press, 1992.

Noll, Mark A., David William Bebbington, George A. Rawlyk. Evangelicalism: Comparative Studies of Popular Protestantism in North America, the British Isles, and Beyond 1700-1900. Oxford, UK: Oxford University Press, 1994.

Onyinah, Opoku. "The Movement of the Spirit Around the World in Pentecostalism." Transformation, Vol. 30, No. 4 (October 2013): 273-286.

Padwick, T. John. "The Spirit Alone": Writing the Oral Theology of a Kenyan Independent Church." Transformation: An International Journal of Holistic Mission Studies, Vol. 35, Issue 1 (April 2018): 15-29.

Ratzinger, Joseph. "The Holy Spirit as Communio: Concerning the Relationship of Pneumatology and Spirituality in Augustine." Communio: International Review,

Vol. 25, No. 2 (1998): 324-339.

Robbins, Joel. "Pentecostal Networks and the Spirit of Globalization On the Social Productivity of Ritual Forms." Berghahn Journals: Social Analysis, Vol. 53, Issue 1 (Spring 2009):55-66.

Sheen, Fulton J. The Divine Romance. Chicago: Brietta Books, 2014.

Swinton, John, Harriet Mowat. Practical Theology and Qualitative Research. London: SCM Press, 2006. 
Practical Theology and Qualitative Research Second Edition. London: SCM Press, 2016.

Tambunan, Elia. Desain Riset: Bagaimana Menulis Proposal Pendidikan, Teologi dan Agama. Yogyakarta: illumination Publishing, 2013.

- Metodologi Riset: Dari Skill Mendesain Proposal Teologi \& PAK hingga Mempublikasikan. Yogyakarta: illumination Publishing, 2012.

Tinklenberg, Jessica L. "It's Somewhere Near the Back: Or, the Simpsons as Model Postmodern Biblical Interpreter." Berkeley Journal of Religion and Theology, Vol. 2, No. 1, Issue 1 (2016): 123-141.

Turner, Max. The Holy Spirit and Spiritual Gifts Then and Now. Carlisle, Cumbria, UK: Paternoster Press, 1996.

White, Ronald C., Charles H. Hopkins. The Social Gospel: Religion and Reform in Changing America. Philadelphia: Temple University Press, 1976.

Yong, Amos. "Toward a Trinitarian Theology of Religions: A Pentecostal-Evangelical and Missiological Elaboration." International Bulletin of Mission Research, Vol. 40, Issue 4 (June 2016): 294-306.

Yun, Koo Dong. Baptism in the Holy Spirit: An Ecumenical Theology of Spirit Baptism. Lanham, Maryland: Universitas Press of America, 2003.

Tentang Penulis:

a. Pdt. Dr. Robby I. Chandra - penulis adalah lecturer di STT Cipanas, Jawa Barat, penulis buku dan juga pendeta emeritus di GKI Kayuputih, Sinode Wilayah Jawa Barat. Email: robbycha@yahoo.com.

b. Pdt. Dr. Elia Tambunan, S.Th, M.Pd - Doktor lulusan UIN Sunan Kalijaga Yogyakarta dengan Disertasi "Islamisme, Kapitalisasi Ruang Kota, dan Gerakan Politik Masyarakat Urban: Aliansi Ekonomi-Politik PKS, Kristen dan Tionghoa di Salatiga;" Pendeta Gereja Pantekosta di Indonesia (GPdI) Wilayah VIII Jawa Tengah; Dosen STT Salatiga; Pendiri Sekolah Alam "Jungle School" Jl. Setyiaki No. 37 Warak, Sidomukti, Salatiga, tahun 2018 murid-muridnya dari 13 Negara. email: elia.tambunan@gmail.com 